\title{
Parasitoids of Gall Inducers on Eucalyptus Clones in Mount Mutis, East Nusa Tenggara Province
}

\author{
Betari Safitri ${ }^{1}$, Lindung Tri Puspasari ${ }^{1}$, Damayanti Buchori ${ }^{2}$, Purnama Hidayat ${ }^{2 *}$ \\ ${ }^{I}$ Study Program Entomology, Graduate School, Faculty of Agriculture, IPB University, Bogor, West Java 16680, Indonesia \\ ${ }^{2}$ Department of Plant Protection, Faculty of Agriculture, IPB University, Bogor, West Java 16680, Indonesia \\ *Corresponding author.Email: phidayat@apps.ipb.ac.id
}

\begin{abstract}
Insect gall inducers are important pests on eucalyptus that formed galls on leaves, twigs, and roots. Many eucalyptus clones have been cultivated and planted for timber production in Sumatera. A study of eucalyptus clone resistance to leaf galls was done in Mt. Mutis, East Nusa Tenggara Province. One of the aims of the study was to identify the parasitoids associated with gall inducers on eucalyptus clones. The research was conducted from October 2017 to July 2018. Fifty-seven clones with 15 plants for each clone were planted in Mt. Mutis, NTT. Galls were observed in the field biweekly for its characteristics and occurrences. Individual galls were collected for rearing to obtain the gall inducers and parasitoids. There were three species of parasitoids identified from two gall inducers. The parasitoid Eurytoma sp. (Hymenoptera: Eurytomidae) emerged from the gall caused by Fergusonina sp. (Diptera: Fergusoninidae) and Ophelimus sp. (Hymenoptera: Eulophidae), Bracon sp. (Hymenoptera: Braconidae) emerged from the gall caused by Fergusonina sp., and Megastigmus sp. (Hymenoptera: Torymidae) emerged from the gall caused by Ophelimus sp. Parasitoid with the highest population was Eurytoma sp. on the gall inducer Ophelimus $\mathrm{sp}$. The basic information of the parasitoids and their hosts on eucalyptus is very valuable data for the development of a biological control program on eucalyptus.
\end{abstract}

Keywords: biological control, Eulophidae, Eurytoma, Hymenoptera, leaf gall

\section{INTRODUCTION}

Based on the latest data from BPS 2017 [1], eucalyptus is the fourth largest timber producer in Indonesia (7.75\%). One problem in eucalyptus cultivation is pests and pathogens. Insect gall inducers are important pests on eucalyptus that formed galls on leaves, twigs, and roots. Gall inducers of eucalyptus in the field can be controlled using natural enemies in the form of parasitoids originating from the order Hymenoptera. Parasitoid is an insect that lives as a parasitein or on the body of another insect (host insect) to take nutrients from the insect as food so that it kills slowly [2].

Parasitoids that are usually used to control gall inducers of eucalyptus are Closterocerus chameolon Girault (Hymenoptera: Eulophidae), Stethynium ophelimi Huber (Hymenoptera: Mymaridae), and Quadratichus mendeli Kim and La Salle (Hymenoptera: Eulophidae) [3]. In addition to these four parasitoids, there are also parasitoids that can suppress gall inducer population originating from the order Diptera and the order Hemiptera. Zelostemma chionocloae Buhl (Hymenoptera: Platygasteridae) is one of parasitoid that can control gall inducer Eucalyptodiplosis sp. (Diptea: Cecidomyiidae) on eucalyptus [4], while parasitoid that can control Glycaspis sp. (Hemiptera: Psyllidae) is Psyllaephagus bliteus Riek (Hymenoptera: Encyrtidae) [5].
All information about species that can control eucalyptus gall inducers are used in many countries, such as India, Australia, South Africa, New Zealand, and USA. Data regarding parasitoid of eucalyptus gall inducers in Indonesia is very limited, so one of the aims of this research is to get basic information about parasitoids that can naturally control gall inducers on eucalyptus. The data can be used to develop biological control program on eucalyptus.

\subsection{Materials and Methods}

The observation was done on October 2017 until June 2018 in Mount Mutis, East Nusa Tenggara. Galls were observed on 855 seedlings from fifty-seven clones with 15 plants for each clone that planted in field, Mount Mutis, East Nusa Tenggara. Eucalyptus seedlings were obtained from Riau and North Sumatra Province that were 3 months old on July 2017. The seedlings planted on October $31^{\text {st }} 2017$ in three different blocks. Observation in the field started two weeks after planted and observed biweekly for gall characteristics and occurrences. Leaves with galls were cut off and stored on plastic. Eucalyptus leaf galls were reared until the insect emerged; the insect was then put into insect Eppendorf tube with $70 \%$ alcohol. 
The insects were identified to the genera level based on morphological characters. Identification was done using identification keys Classification of Chalcid Flies (Superfamily: Chalcidoidea) [6], Manual of Nearctic Diptera [7], dan Guide to Aquatic Invertebrates of The Upper Midwest (Diptera: (Aquatic and Semiaquatic True Flies)) [8]. Identification and photograph were carried out using stereo microscope Olympus SZ51 and Leica M205C with digital camera Leica DFC450 and LAS V.4.4.0 application (Build: 454) that are connected to a computer. Insects that have been identified were then distinguished based on their role in the form of gall inducers or parasitoids. Level of parasitism were calculated to find out how effective the parasitoids can control gall inducers.

\subsection{Our Contribution}

This paper discusses the potential of parasitoids for biological control of eucalyptus gall inducers. Insects that emerged naturally from gall inducers can be interpreted to be the natural enemy of gall inducers, called parasitoid. Some phytophagous insects serve as a trigger for the existence of parasitoids. The interaction between host and parasitoid population indicates that the food chain is occurring. The use of suitable parasitoid for the development of gall inducer biological control is done by counting the number of individual parasitoid and the level of parasitism. This research could obtain information on parasitoids and their hosts on eucalyptus which is a very valuable data for the development

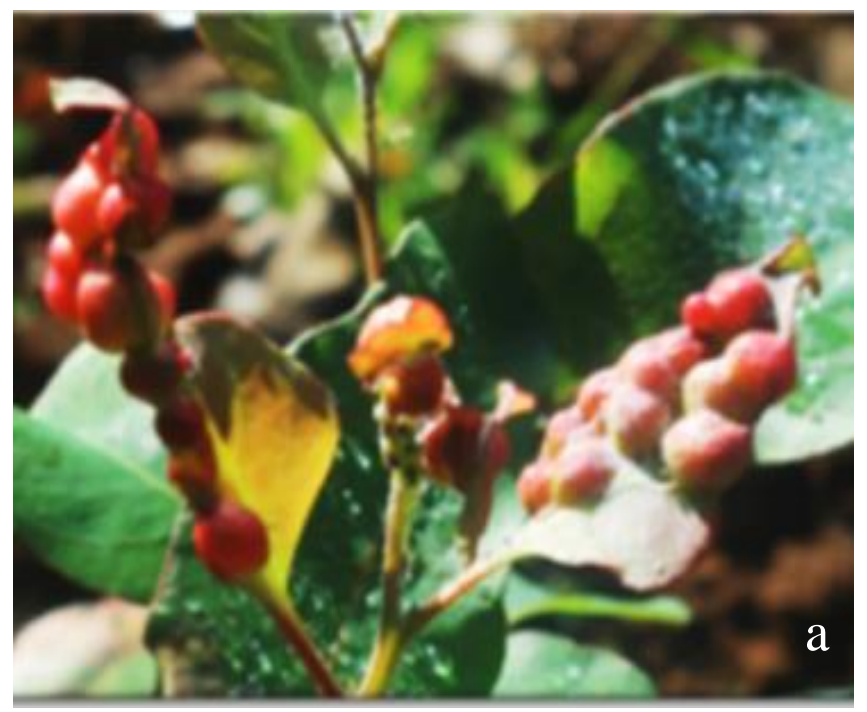

of biological control program for the eucalyptus forest industry.

\subsection{Paper Structure}

The rest of the paper is organized as follows. Section 2 explains there were three parasitoid species that emerged from two gall inducers. This section tells about the parasitoids emerged from two different shapes of gall in eucalyptus and level of parasitism. In addition, this section tells about morphological characters and other characters from parasitoids that emerged from the galls. These results are newly reported in Indonesia and discussed with that conducted in Mt. Mutis. Finally, section 3 concludes the most dominant parasitoid found from gall inducers and the present biological control program on eucalyptus forest industry.

\section{RESULTS AND DISCUSSION}

There were three species of parasitoids of gall inducers identified from two gall inducers, Fergusonina sp. (Diptera: Fergusoninidae) and Ophelimus sp. (Hymenoptera: Eulophidae). Galls that were caused by two different gall inducers had different shapes (Figure 1). The parasitoids of gall inducers were Eurytoma sp. (Hymenoptera: Eurytomidae), Bracon sp. (Hymenoptera: Braconidae), and Megastigmus sp. (Hymenoptera: Torymidae) (Figure 2).

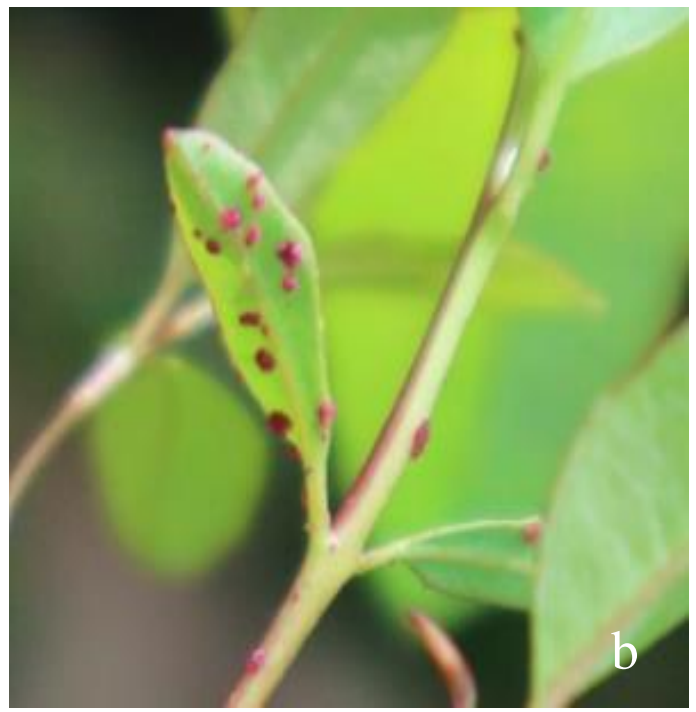

Figure 1 Leaf gall shapes on eucalyptus from two gall inducers: (a) Fergusonina sp., (b) Ophelimus sp. 


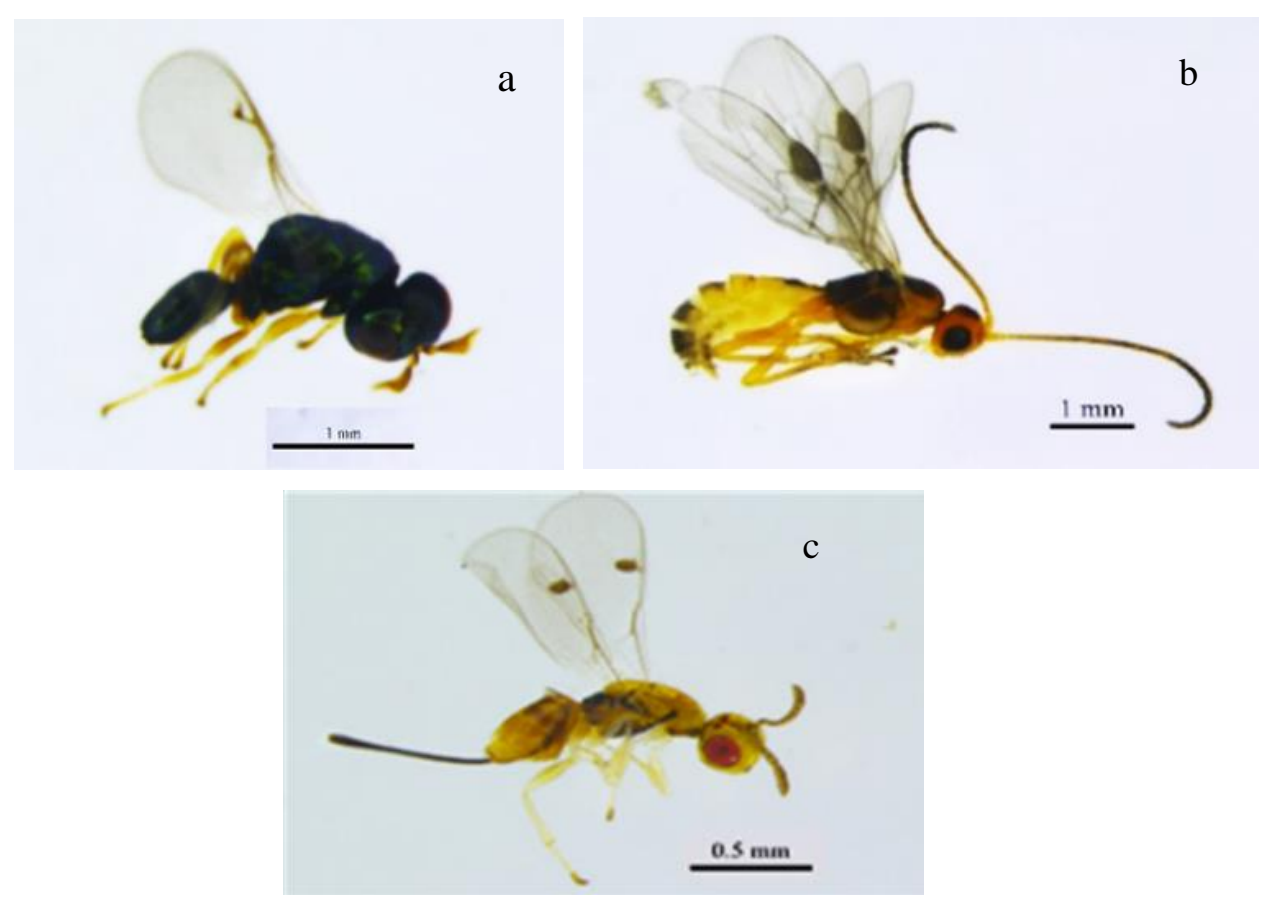

Figure 2 Parasitoids that were found from two gall inducers on eucalyptus: (a) Eurytoma sp. (b) Bracon sp. and (c) Megastigmus sp.

There was one parasitoid that emerged from two different gall inducers, it was Eurytoma sp. (Figure 2a). Eurytoma sp. had morphological characters as follows, black and not metallic body color; male length was smaller than female length at $1.23-1.30 \mathrm{~mm}$; the antennae had yellow brownish color with one segment of scapus and pedicel, four segments of funicles and three segments of clavate [9]. Eurytoma sp. emerged from two different gall inducers, Fergusonina sp. and Ophelimus sp. In this research the level of parasitism of Eurytoma sp. on Fergusonia sp. was $22.22 \%$ it was lower than the level of parasitism on Ophelimus sp., at about 50\%. Eurytoma sp. is a genus from the Family Eurytomidae that is grouped as parasitoid, because not all species in this family are as parasitoid. Biology of Eurytomidae varies greatly with the majority of species are parasitoid and the minority are phytophagous insects, including gall inducers [10]. Meanwhile other parasitoid that emerged from gall inducers was Bracon sp. (Figure 2b). Bracon sp. had yellow body with 19 segments on its antennae. The rear wings had $2 \mathrm{~m}$-cu veins and $1 \mathrm{r}-\mathrm{m}$ veins was usually separated into R1 and Rs [11]. Although Bracon sp. was one of the general parasitoids that usually are found naturally or when rearing pest to find out about its parasitoid, in this research the level of parasitism of Bracon sp. was the lowest from the three species of parasitoid that emerged from gall inducers, at about $11.11 \%$. Bracon sp. only emerged from Fergusonina sp., meanwhile Eurytoma sp. and Bracon sp. emerged from the galls caused by Fergusonina sp. Both Eurytoma sp. and Bracon sp are usually used to control gall inducers in Australia, South Africa, Brazil, and India Wylie dan Speight 2012 [12]. Eurytoma sp. and Bracon sp. parasitize the larvae and pupa of insects from the order Lepidoptera and Diptera.

The third parasitoid that emerged was Megastigmus sp. (Figure 2c). Adult Megastigmus sp. body had yellow dominant color with brown spots and the length of the body is the same as the length of the ovipositor. In addition, the adult had hyaline wings, yellow veins, and dark brown stigma. The antennae were clavate with transverse flagellum segments of the same length [13]. Megasitgmus sp. emerged from the gall inducer Ophelimus sp. and had parasitism level of $42.85 \%$. According to previous researches, Eurytoma sp. and Megastigmus sp. are parasitoid that can control Ophelimus sp. naturally. The parasitoid that found will be indentified until species with morphological and molecular characteristics. In addition, the parasitoids obtained will be propagated and tested in the field to control the gall inducers.

\section{CONCLUSION}

The most dominant parasitoid based on the level of parasitism on two gall inducers, Ophelimus sp. and Fergusonina sp. was Eurytoma sp. The basic information of the parasitoids and their hosts on eucalyptus is very valuable data for the development of a biological control program for the eucalyptus forest industry. 


\section{ACKNOWLEDGMENT}

This research was funded by PT RAPP (collaborative research between IPB University and PT RAPP). Deepest gratitude to the Ministry of Environment and Forestry for providing research opportunities in Mt. Mutis, NTT.

\section{REFERENCES}

[1] BPS [Badan Pusat Statistik], Statistik Produksi Kehutanan, Badan Pusat Statistik, Jakarta, 2017

[2] A. Bonet, Parasitoid wasps, natural enemies of insects. Tropical Biology and Conservation Management, 2008, http://www.eolss.net/sample.../c20/e6-142-tpe-29.pdf

[3] I.K. Kim, J. La Salle, A new genus and species of Tetrastichinae (Hymenoptera: Eulophidae) inducing galls in seed capsules of Eucalyptus, Zootaxa. (2008) 1754-6368

[4] P.N. Buhl, Mc.S. Sarfati, E.G. Brokerhoff, D. Kelly, Description, phenology, and biology of Zelostemma chionochloae Buhl sp. nov., a platygastrid parasitoid of Eucalyptodiplosis chionochloae (Diptera: Cecidomyiidae) in New Zealand, N Z J Zool. 35 (2010) 255-264.

DOI:https://doi.org/10.1080/03014220809510122

[5] V. Caleca, G.L. Verde, M. Maltese, First record in Italy Psyllaephagus bliteus Riek (Hymenoptera Encyrtidae) parasitoid of Glycaspis brimblecombei Moore (Hemiptera: Psyllidae), Nat Sicil. 4,35(3-4) (2011) 435444

[6] W.H. Ashmead, H.H. Smith, Classification of the Chalcid Flies: or the superfamily Chalcidoidea, with descriptions of new species in the Carnegie Museum, collected in South America by Herbert H. Smith: authority of the Board of Trustees of the Carnegie Institute, 1904

[7] J.F. McAlpine, B.V. Peterson, G.E. Shewell, J.H. Teskey, J.R. Vockeroth, D.M. Wood, Manual of Nearctic Diptera, Canadian Government Publishing Centre, Ottawa, 1981

[8] R.W. Bouchard, Guide to Aquatic Invertebrates of The Upper Midwest. Water Resources Centre, University Minnesota, St. Paul, Minnesota, 2004

[9] Z. Boucek, Descriptions of Tachinobia gen. n. and three new species of Tetrastichinae (Hymenoptera: Eulophidae), with a tentative key to genera, Bull Entomol Res. 7(01) (1977) 17-30

[10] DiGaulio, Eurytomidae. In: Gibson, G.A.P., Huber, J.T., Woolley, J.B. (Eds.), Annotated Keys to the Genera of
Nearctic Chalcidoidea (Hymenoptera), National Research Council (NRC) of Canada, Ottawa, 1998, pp. 477-495.

[11] M.J. Sharkey, Family Braconidae. In Goulet H, Huber JT, ed. Hymenoptera of the World: An identification guide to families, Canada Communication Group Publishing, Ottawa, 1993.

[12] F.R. Wylie, M.R.Speight, Insect Pest in Tropical Forestry 2nd ed. CPI Group (UK) Ltd, Crydon, Oxford, 2012.

[13] M. Doğanlar, E. Hassan, Review of Australian species of Megastigmus (Hymenoptera: Torymidae) associated with Eucalyptus, with descriptions of new species, Aust J Basic Appl Sci. 4(10) (2010) 5059-5120 